\title{
42. REGIONAL SETTING OF SITE 357, NORTH FLANK OF RIO GRANDE RISE ${ }^{\prime}$
}

\author{
Scott McDowell, ${ }^{2}$ Naresh Kumar, ${ }^{3}$ Robert D. Jacobi, ${ }^{3}{ }^{4}$ David A. Johnson, ${ }^{5}$ and Elizabeth T. Bunce ${ }^{5}$
}

\begin{abstract}
Underway geophysical data (bathymetric, seismic reflection and refraction, gravity, and magnetics) have been examined for approximately $1000 \mathrm{~km}$ of track lines within one-degree square near Site 357 on the north flank of the Rio Grande Rise. This examination allows a preliminary interpretation of the physiography, structure, and depositional history for the area around Site 357.

The east-west segment of the Rio Grande Rise probably originated approximately 100 m.y. ago as a group of volcanic islands composed of alkalic basalt. A layer, approximately $1 \mathrm{~km}$ thick, perhaps composed of extrusive volcanics mixed with sediment, appears to separate the oceanic basement from the sedimentary column overlying it. The deepest reflector noticed throughout the rise does not represent the oceanic basement, but, rather, the top of a marly limestone of Santonian age. This limestone varies in thickness throughout the rise and overlies the extrusive volcanic layer. The intermediate reflectors noticed in the seismic profiles represent diagenetic changes within the sedimentary column.

The north flank of the rise is deeply dissected by erosional canyons which become well developed below a depth of approximately 1500 meters. These canyons have in some cases eroded several hundred meters into the carbonate sediments of Cenozoic and possibly Upper Cretaceous age. Seismic profiles and piston coring confirm that pre-Pleistocene strata outcrop on the canyon flanks. Consequently there is a substantial local variation in the completeness of the deposition record at any given location. The origin of the canyons is uncertain, but the piston-core data indicate extensive development only in the late Cenozoic.

The contrast in the stratigraphy of Sites 357 and 22, both located on the rise within $30 \mathrm{~km}$ of each other, points to the need for caution in interpreting the significance of unconformities at a single drill site. Regional inferences from the presence of an unconformity at a single site must be made in conjunction with the assessment of possible local erosional events.
\end{abstract}

\section{INTRODUCTION}

The Rio Grande Rise (Figure 1) and the Walvis Ridge (Connary, 1972; Goslin et al., 1974; Goslin and Sibuet, 1975) constitute the two major aseismic rises of the South Atlantic Ocean (Sclater and McKenzie, 1973). The Rio Grande Rise divides the western South Atlantic into two basins: the Argentine Basin located to the south and the Brazil Basin located to the north.

'Contribution No. 3696 of the Woods Hole Oceanographic Institution.

${ }^{2}$ Graduate School of Oceanography, University of Rhode Island, Kingston, Rhode Island.

${ }^{3}$ Lamont-Doherty Geological Observatory of Columbia University, Palisades, New York.

¿Also at Department of Geological Sciences, Columbia University, New York.

sWoods Hole Oceanographic Institution, Woods Hole, Massachusetts.
The rise itself has been subdivided physiographically into two principal parts: a landward east-west segment and a seaward north-south segment (Lonardi and Ewing, 1971; Francheteau and Le Pichon, 1972). The Vema Channel lies to the west of the rise (Le Pichon et al., 1971), and the Hunter Channel lies to the east (Burckle and Biscaye, 1971). The total area occupied by the rise extends between $28^{\circ}$ and $40^{\circ} \mathrm{W}$ longitudes and $28^{\circ}$ and $34^{\circ} \mathrm{S}$ latitudes. Figure 1 shows the general bathymetry of the main east-west segment; the northsouth segment, located to the east of the main plateau, is not shown in its entirety.

The origin of the Rio Grande Rise, as well as of the Walvis Ridge, is not well understood. Both features have been explained as either related to "hot-spot" activity under the mid-ocean ridge (Morgan, 1971; Wilson, 1973), or generated partly as "marginal fracture ridges" along major fracture zones and partly as a consequence of a change in spreading direction (Le 


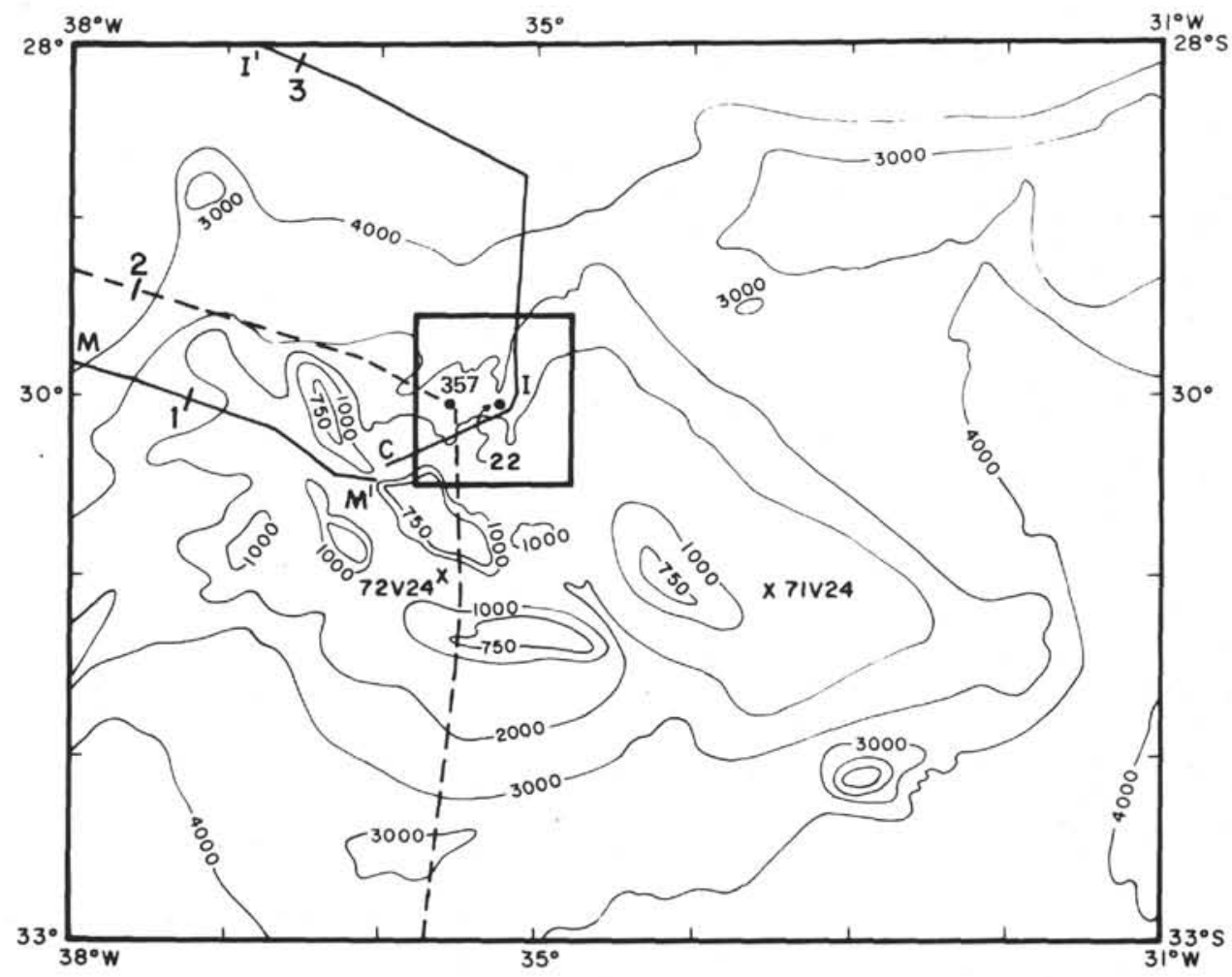

Figure 1. Bathymetry of the east-west segment of the Rio Grande Rise (contours in corrected meters from Connary and Moody, L-DGO unpublished map). Solid line indicates track of R/V Conrad, Cruise 16-10; dashed line is track of Glomar Challenger (Leg 39). Locations of DSDP Sites 22 and 357 are shown. Crosses mark the locations of sonobuoy stations $71 \mathrm{~V} 24$ and $72 \mathrm{~V} 24$. The box indicates the region of detailed investigation, shown in Figures 2, 3, 4, 5, 9, and 10. Profiles $M M^{\prime}$ and $I I^{\prime}$ shown in Figure 7. Locations marked as 1, 2, and 3 discussed in text.

Pichon and Hayes, 1971; Francheteau and Le Pichon, 1972).

A survey of the north flank of the Rio Grande Rise was conducted in January 1969 (R/V Vema, Cruise 26) prior to drilling at a suitable site during Leg 3 of the Deep Sea Drilling Project (Maxwell, Von Herzen, et al., 1970). Subsequently, Site 22 was drilled within the Vema 26 survey area at latitude $30^{\circ} 00.31^{\prime} \mathrm{S}$ and longitude $35^{\circ} 15.00^{\prime} \mathrm{W}$ (Figures 1 and 2). However, geological results from the data of Site 22 were of limited value because the drill site penetrated to a subbottom depth of only 242 meters. The thick sediment accumulation atop the rise remained largely unsampled.

Two additional cruises of the Lamont-Doherty Geological Observatory (L-DGO) (R/V Robert D. Conrad, Cruise 15 in 1972 and Cruise 16 in 1973) have provided supplementary data for the north flank of the rise. During April-May of 1974, the R/V Chain of the Woods Hole Oceanographic Institution (WHOI) returned to the Rio Grande Rise and carried out a survey and sampling program approximately $30 \mathrm{~km}$ west of Site 22. From an analysis of the data obtained during the Chain 115 survey (Johnson, 1974), a drill site was proposed to obtain additional biostratigraphic information on the north flank of the Rio Grande Rise. Consequently, during DSDP Leg 39, Site 357 was drilled at latitude $30^{\circ} 00.00^{\prime} \mathrm{S}$ and longitude $35^{\circ} 34.7^{\prime} \mathrm{W}$. This report presents geological and geophysical data within a one-degree square (bounded by latitudes $29^{\circ} 30^{\prime} \mathrm{S}$ and $30^{\circ} 30^{\prime} \mathrm{S}$ and longitudes $34^{\circ} 45^{\prime} \mathrm{W}$ and $35^{\circ} 45^{\prime} \mathrm{W}$ ) that includes both Sites 22 and 357 . The data provide a framework within which the drilling results of the two sites can be interpreted.

\section{MORPHOLOGY}

The north flank of the Rio Grande Rise slopes downward from the topographic highs at the summit (depth less than $800 \mathrm{~m}$ ) to the southern margin of the Brazil Basin (depth $>4000 \mathrm{~m}$; Figure 1). Bathymetric data from L-DGO and WHOI cruises have been combined to map the small-scale physiographic features in the vicinity of Sites 22 and 357 . Figure 2 illustrates the extensive coverage of cruise tracks on the north flank of the rise from which the bathymetric data for this paper were obtained. Figure 3 is a bathymetric map of the survey region.

The north flank of the rise is dissected by an extensive system of erosional canyons which become well developed below a depth of approximately 1500 meters (Figure 3 ). The canyons are generally 5 to $20 \mathrm{~km}$ wide and several hundred meters deep; they become deeper and broader toward the north (downslope). Where the canyons widen, they often merge with 


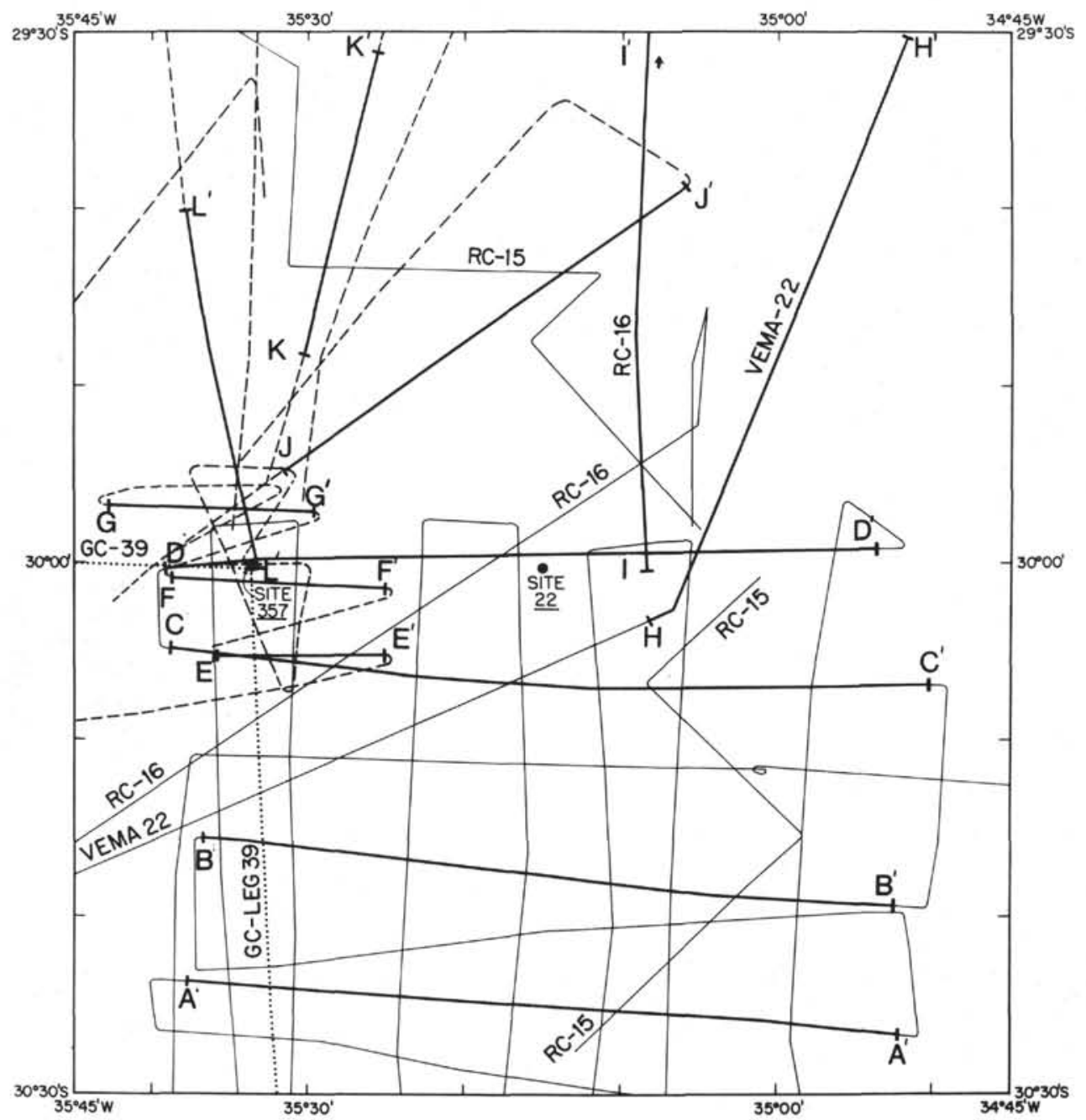

Figure 2. Ship tracks in the vicinity of DSDP Sites 22 and 357. Heavy solid lines (labeled $A A^{\prime}, B B^{\prime}$, etc.) indicate tracks for which seismic reflection profiles are shown in Figures 6 through 8. Other tracks shown are as follows: Solid line - L-DGO cruises, dashed lines - Chain 115, Leg 6; dotted lines - Glomar Challenger, Leg 39.

adjacent canyons to form broad topographic depressions, suggesting that they may have been formed by bottom currents flowing down the slope of the rise. The evidence for such erosional events is discussed later.

\section{GRAVITY AND MAGNETICS}

Figure 4 is a map of free-air gravity anomaly patterns within the survey area drawn at a contour interval of 5 mgal. The total range in gravity anomalies in this area is of the order of $85 \mathrm{mgal}$. In general, the gravity anomaly pattern parallels the bathymetry, with the highest positive anomalies (70 $\mathrm{mgal})$ located in the shallowest parts of the area (see Figure 3). The anomalies decrease sharply in amplitude over the flanks of the rise, and the largest negative anomalies $(-15$ mgal) are located in the deepest part of the survey area in the canyon axes. The horizontal gradient of the contoured gravity anomalies across the flank of the rise $(28 \mathrm{mgal} / \mathrm{km})$ is significantly smaller than that expected either from an uncompensated sediment pile or from an uncompensated basement ridge covered with sediment (Embley and Hayes, 1972). Hence, a gravimetric compensation at depth is implied.
Although the magnetic anomalies presumably caused by sea-floor spreading are well developed to the north and south of the Rio Grande Rise, the patterns of magnetic anomalies on the rise itself are difficult to identify. Ladd (1974) has shown the anomaly-34 location to be almost coincident with the $33^{\circ} \mathrm{W}$ meridian (Figure 1). If so, then the survey area and most of the Rio Grande Rise may be located within the Late Cretaceous "magnetic-quiet zone" (Larson and Pitman, 1972). Assuming a half-spreading rate of 4.5 $\mathrm{cm} / \mathrm{yr}$ prior to $84 \mathrm{~m} . \mathrm{y}$. B.P. (Larson and Ladd, 1973), Site 357 should be located over crust approximately 90 m.y. old and the western edge of the rise should be approximately 95 m.y. old.

Figure 5 is a contour map of the residual magnetic anomaly drawn at a contour interval of 50 gammas. Shaded areas indicate local magnetic highs. Within the region the total range in the magnetic anomalies is 600 gammas, and the overall trend follows that of the local gravity and topography.

A "ridge" in the gravity-anomaly pattern (Figure 4) and a series of magnetic highs (Figure 5) trending in a west-northwest-east-southeast direction are seen in the 
southern part of the survey area. This area is also one of the shallowest parts of the Rio Grande Rise (Figures 1 and 3 ). We do not know whether this trend continues beyond the survey area, but it might coincide with the regional shoaling of acoustic basement under the rise observed in seismic profiles.

\section{SEISMIC DATA}

Seismic-reflection profiles were obtained along all cruise tracks shown in Figure 2. Representative sections (labeled $\mathrm{AA}^{\prime}$ through $\mathrm{MM}^{\prime}$ on Figures 1 and 2) are presented in Figures 6 through 8. The seismic profiles clearly indicate one or two intermediate horizons underlain by a highly reflective deep horizon. Although the deepest reflector of Profile $\mathrm{AA}^{\prime}$ (Figure 6) changes in character from irregular to smooth (Profiles $\mathrm{CC}^{\prime}$, $\mathrm{DD}^{\prime}$ ), it can be followed throughout the survey region (Figures 6 through 8 ) and corresponds to the deepest reflector observed at $0.78 \mathrm{sec}$ at Site 357 (see chapter on Site 357 , this volume). Above this horizon the sediment cover has been deeply dissected by erosional channels.
In portions of profiles $\mathrm{BB}^{\prime}, \mathrm{CC}^{\prime}$, and $\mathrm{DD}^{\prime}$ (Figure 6) where the bottom morphology is relatively smooth, two distinct intermediate reflectors are evident. In other profiles, however, it is difficult to recognize them individually because a third and wide reflector can be seen, spanning the depth range of both of the intermediate reflectors. The uppermost of the two intermediate horizons corresponds with Reflector 1 (measured at $0.24 \mathrm{sec}$ ) on the seismic record obtained by Glomar Challenger while approaching Site 357; the lower horizon corresponds with Reflector 2 at $0.38 \mathrm{sec}$ on the Challenger record (see chapter on Site 357, this volume).

An isopach map of sediment thickness over the deepest observed reflector has been constructed (Figure 9) from all tracks shown in Figure 2, using a contour interval of $0.10 \mathrm{sec}$ two-way travel time. The total sediment thickness overlying the deepest reflector ranges from $0.3 \mathrm{sec}$ to $1.10 \mathrm{sec}$ of two-way travel time, representing 300 to 1100 meters at an average velocity of $2.0 \mathrm{~km} / \mathrm{sec}$. A second isopach map (Figure 10)

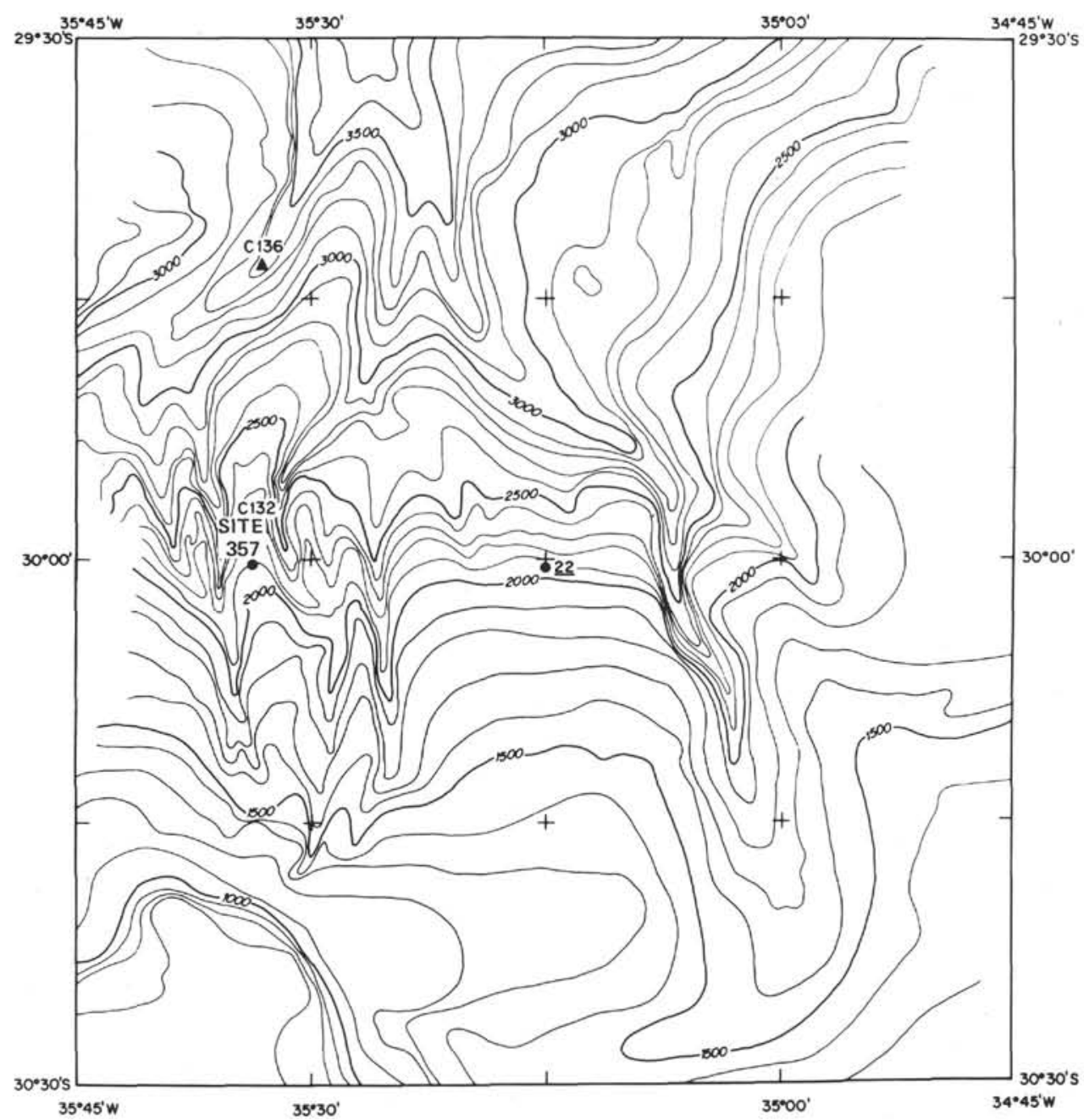

Figure 3. Bathymetry of the north flank of the Rio Grande Rise in the vicinity of DSDP Sites 22 and 357. Contours are in corrected meters; contour interval is 100 meters. Note the extensive development of canyon system in depths greater than approximately 1500 meters. Triangles indicate the locations of bottom photographs shown in Figures $11 a$ and $b$ (Station 132) and 11c and d (Station 136). 


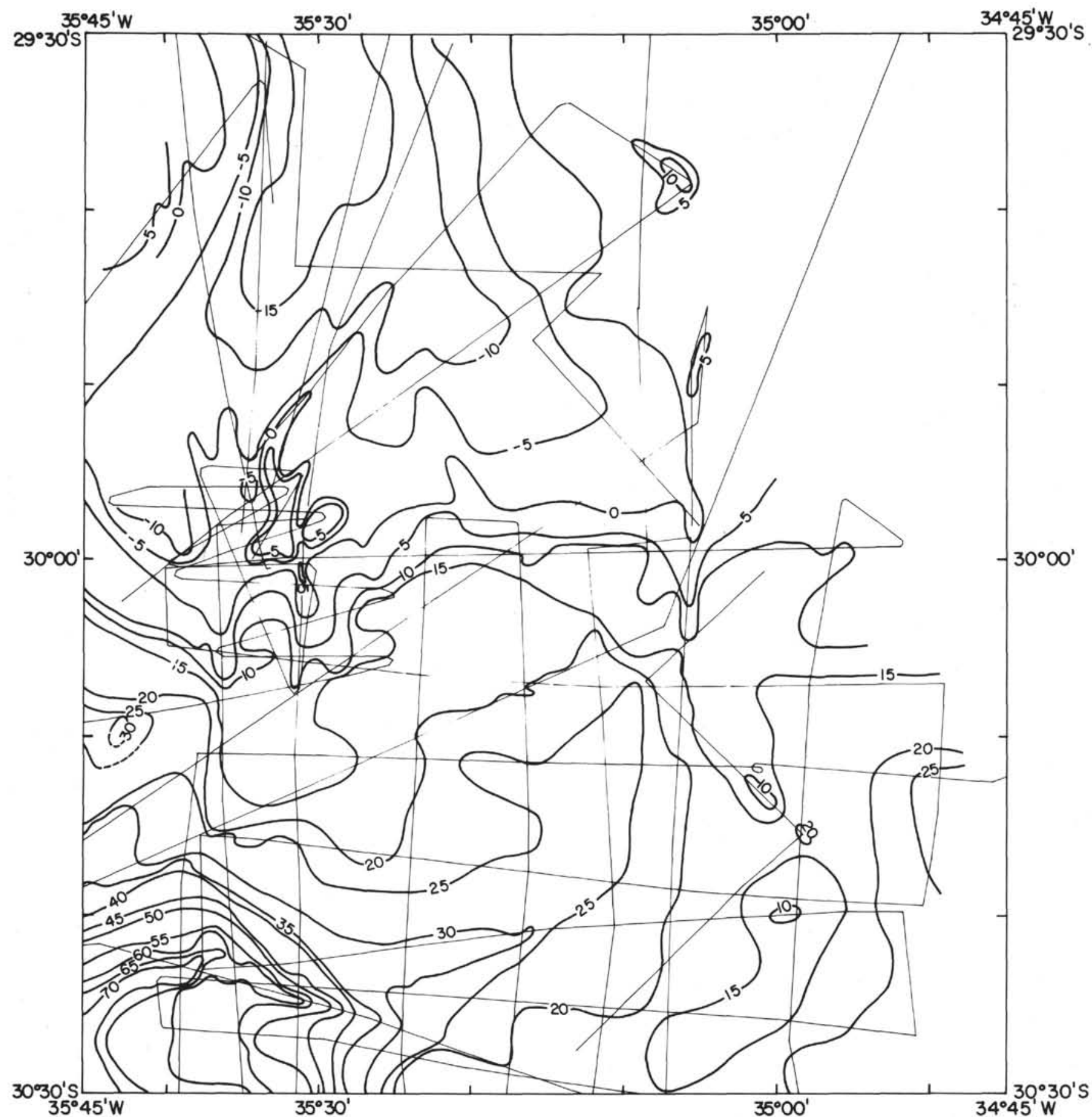

Figure 4. Free-air gravity anomaly on the north flank of Rio Grande Rise. Contour interval is 5 mgal.

displays the sediment thickness in two-way travel time between the sea floor and Reflector 1. Sediment thickness in this layer ranges from less than $0.10 \mathrm{sec}$ to $0.70 \mathrm{sec}$.

Prior to drilling at Site 357, the deepest reflector in the area (Figure 6) was believed to represent igneous basement, but ultimately this reflector proved to mark a diagenetic change from chalk to limestone (see chapter on Site 357, this volume). From the available seismic data, some postulates may be made as to the depth and nature of the basement below the limestone reflector.

L-DGO dredges from the Rio Grande Rise (R/V Robert D. Conrad Cruise 16-10, 1973, dredges 11 and 12 from the summit of the rise) have yielded olivine basalt, volcanic glass, and weathered lava (Fodor et al., in press). Eocene volcanics were drilled at Site 357 (see chapter on Site 357, this volume) and appear to have been derived from oceanic islands on the top of the rise (Fodor et al., 1975). For these reasons and because 


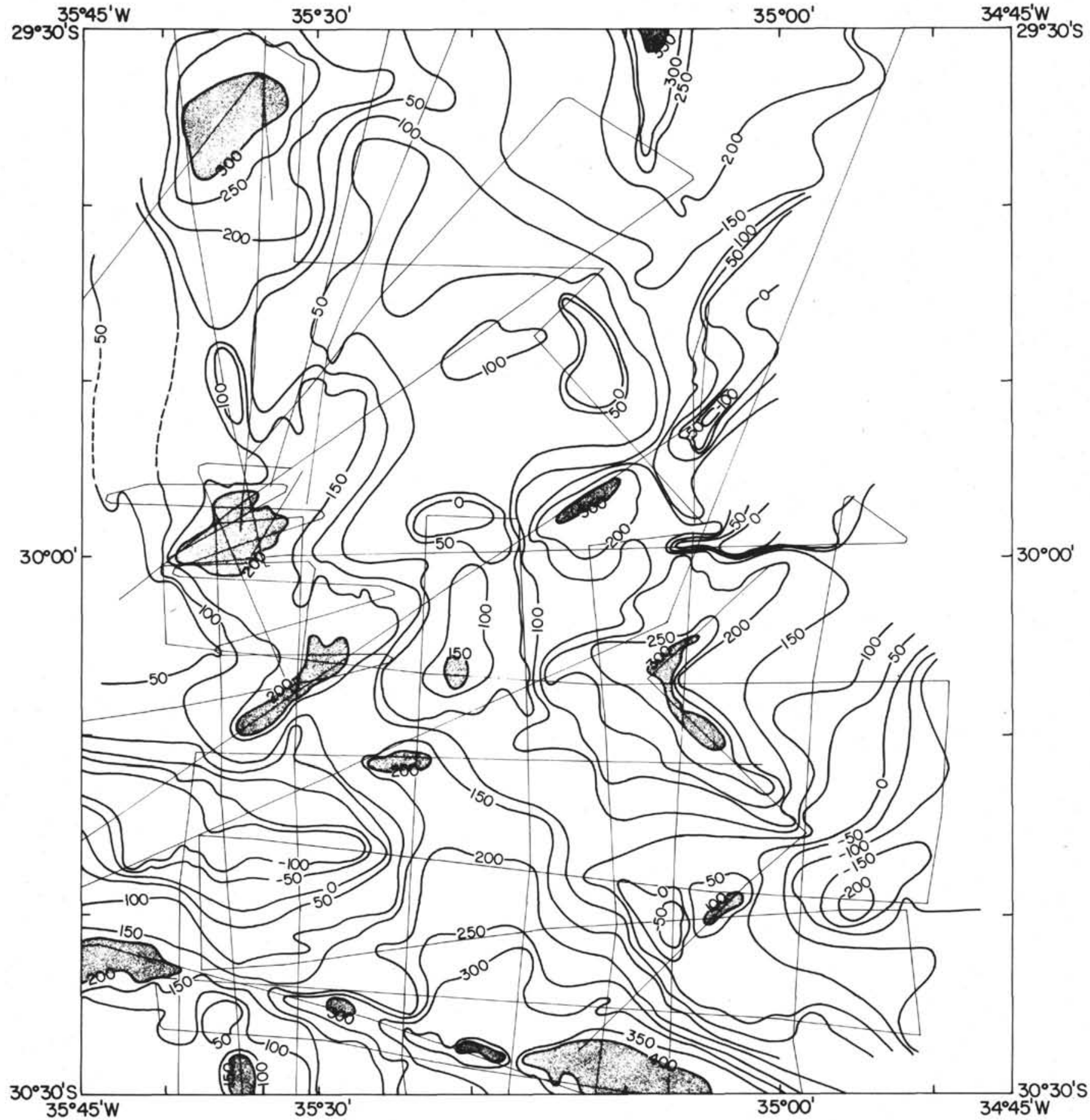

Figure 5. Contour map of residual magnetic anomaly in the survey area at a contour interval of 50 gammas.

large magnetic anomalies are associated with the rise, it seems safe to predict that the rise consists of basic igneous rocks. Preliminary analysis of specimens indicate that they are not oceanic tholeiites but rather have alkaline affinities (Fodor et al., 1975; in press).

Some of the sonobuoy profiles from the rise also provide useful information concerning the nature of basement beneath the rise. Sonobuoy 72V24 (Figure 1) revealed the following seismic section: (1) an upper sedimentary layer (assumed velocity $2.3 \mathrm{~km} / \mathrm{sec}$ ) 920 meters thick, (2) a middle layer (velocity $3.6 \mathrm{~km} / \mathrm{sec}$ ) 850 meters thick, and (3) a lower layer (velocity 4.3 $\mathrm{km} / \mathrm{sec}$ ) of unknown thickness, which, on the basis of its velocity, may represent oceanic basement (Ewing, 1969).

Sonobuoy profile $71 \mathrm{~V} 24$ (location shown on Figure 1) resulted in the following seismic section: (1) an upper sedimentary layer (assumed velocity $2.3 \mathrm{~km} / \mathrm{sec}$ ) 550 meters thick, (2) a middle layer (assumed velocity 3.5 $\mathrm{km} / \mathrm{sec}$ ) 900 meters thick, and (3) a lower layer 
(velocity $4.7 \mathrm{~km} / \mathrm{sec}$ ) of unknown thickness, again probably representing oceanic basement. The basal reflector of the Rio Grande Rise sequence (the limestone reflector) is observed at a subbottom depth of approximately 550 meters in the profiler record at the location of sonobuoy $71 \mathrm{~V} 24$. Although the profiler record at the locations of both sonobuoys shows no
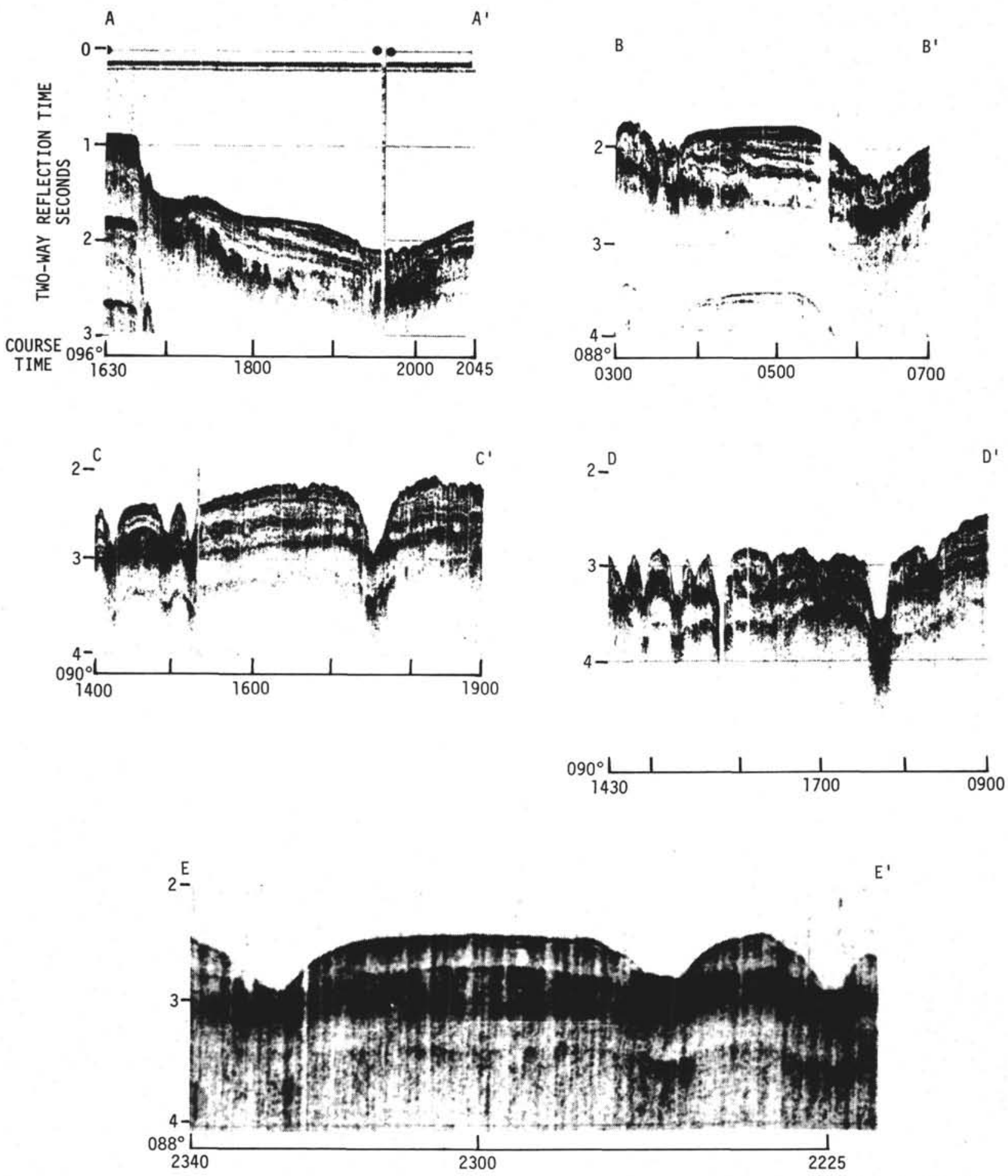

Figure 6. West-east seismic profiles in the vicinity of Sites 22 and 357 on the north flank of Rio Grande Rise. Profile locations are shown on Figure 2. Note the development of extensive canyons below $2.0 \mathrm{sec}$ (approximately $1500 \mathrm{~m}$ ) and the outcropping of almost horizontal acoustic reflectors in the canyon walls.

reflector deeper than the limestone reflector, refraction data suggest that the limestone reflector is separated from the oceanic basement by a layer approximately 1 $\mathrm{km}$ thick with an average velocity of $3.6 \mathrm{~km} / \mathrm{sec}$.

As mentioned earlier, a linear extrapolation of crustal age from the position of anomaly 34 gives an approximate age of 90 m.y. for the oceanic crust under
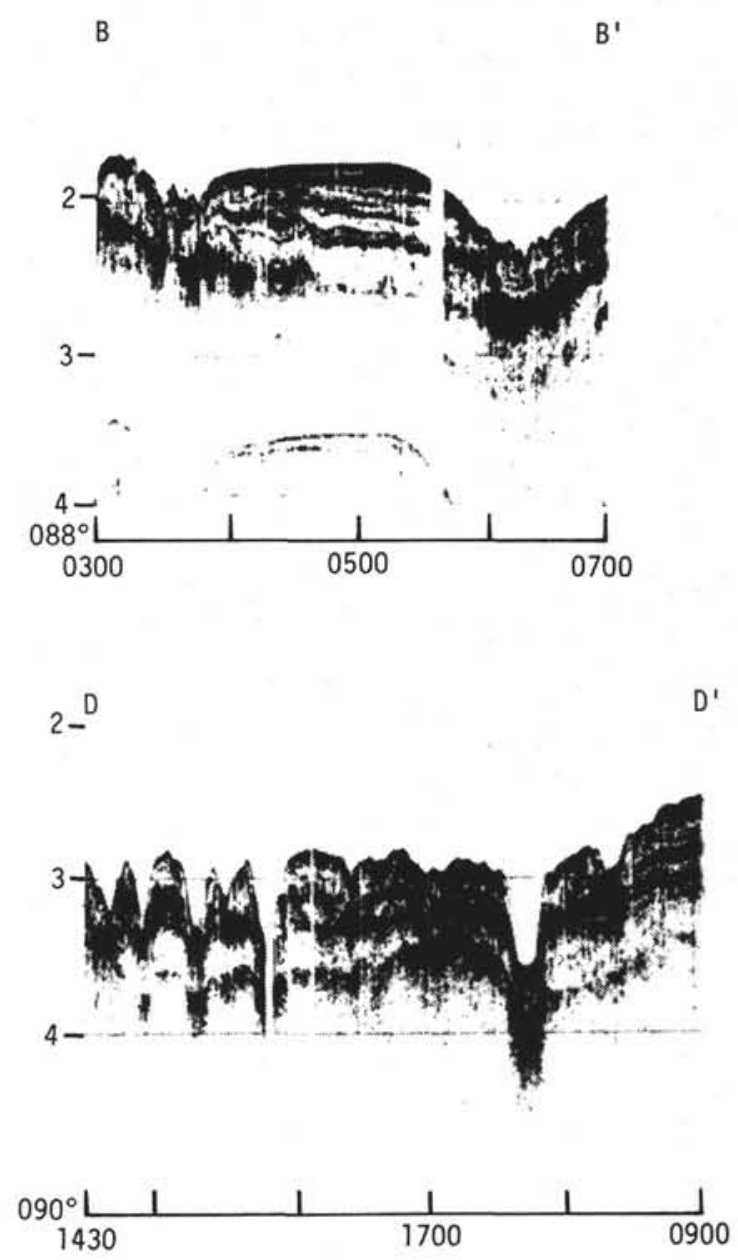

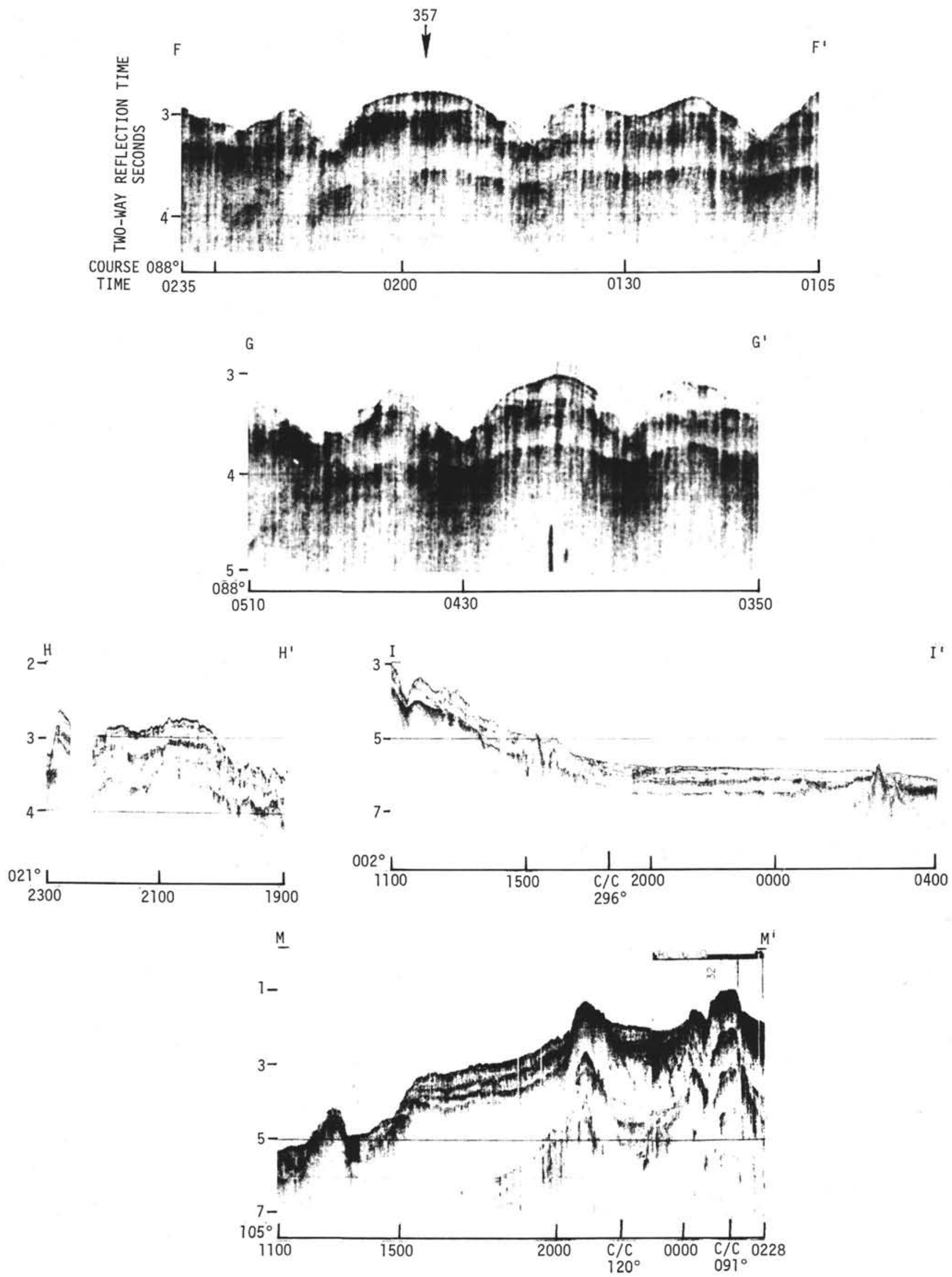

Figure 7. Seismic profiles in the vicinity of DSDP Site $357\left(F F^{\prime}, G G^{\prime}\right)$, and extending down the north flank of the Rio Grande Rise $\left(H H^{\prime}, I I^{\prime} . M M^{\prime}\right)$. Locations of profiles $I I^{\prime}$ and $M^{\prime} M^{\prime}$ shown in Figure 1; other profile locations shown in Figure 2. Projected location of Site 357 shown in Profile FF'. 


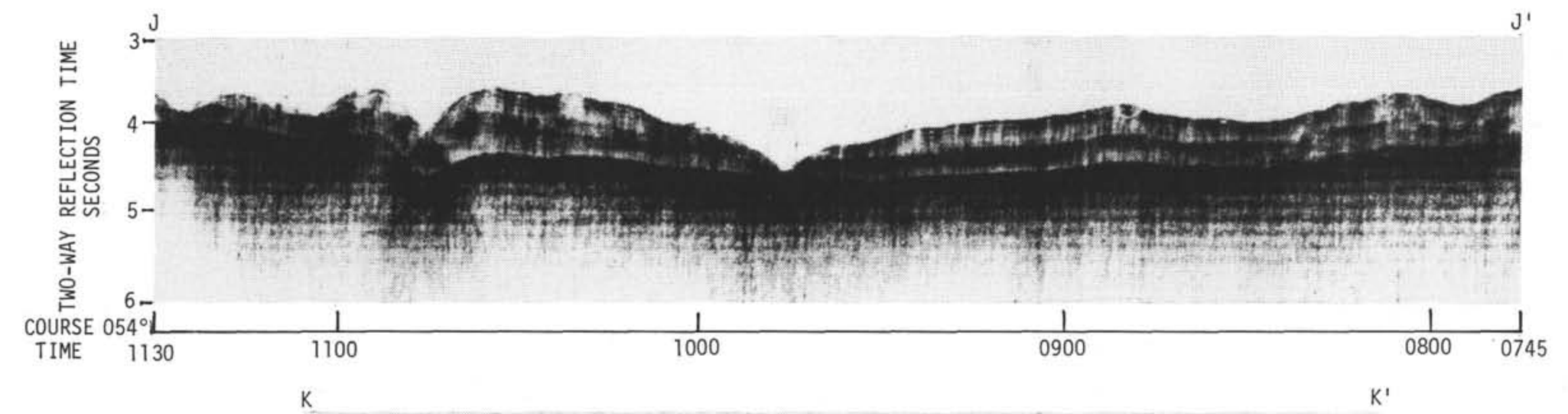

$K^{\prime}$

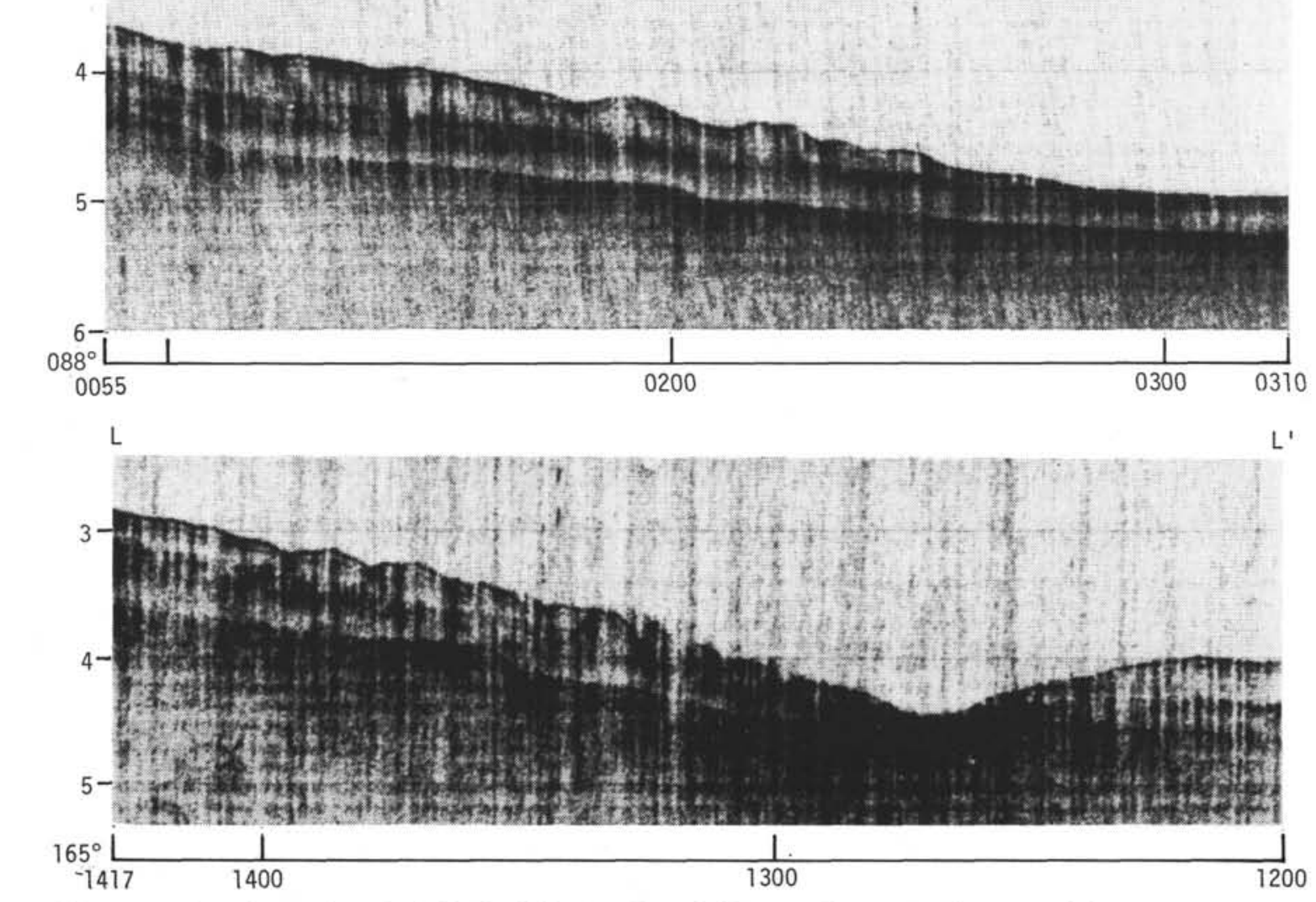

Figure 8. Seismic profiles extending down the north flank of the Rio Grande Rise, and crossing the axes of the canyon system at a low angle. Locations of these profiles shown in Figure 2. 


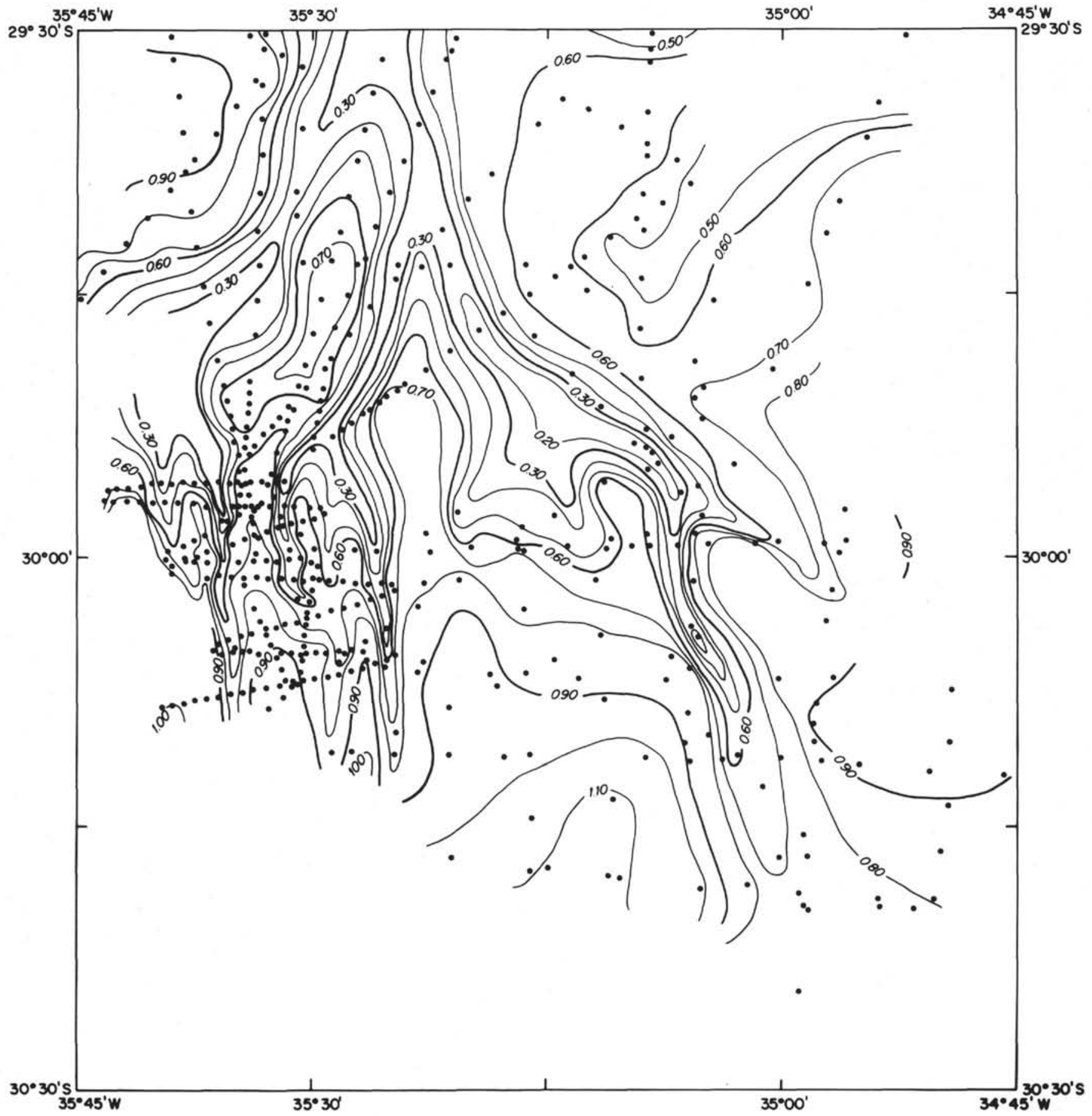

Figure 9. Sediment thickness above the deepest observed reflector on the seismic profiles (see Figures 6 through 8). This deepest reflector has been designated as Reflector 3 and marks the top of the Santonian marly limestone (see chapter on Site 357, this volume). Contour interval is 0.10 sec two-way travel time.

Site 357. The oldest sediments drilled at the site are Santonian (approximately 80 m.y.), an age close to the extrapolated basement age. We should, therefore, not expect a sedimentary sequence representing more than 10 m.y. of geological history beneath the oldest sediments drilled. However, based on the estimated subsidence rates for various parts of Rio Grande Rise, Thiede et al. (1975, see also Site 357 chapter, this volume) have suggested that the crust beneath Site 357 may be as much as $20 \mathrm{~m} . \mathrm{y}$. older than the oldest sediments drilled at the site. Further drilling in the area may solve the question.

If our extrapolation for the age of the crust at Site 357 is valid, then we suggest that the 1-km-thick, 3.6 $\mathrm{km} / \mathrm{sec}$ layer underlying the limestone reflector cannot represent exclusively sediment accumulation. An accumulation of $1 \mathrm{~km}$ in $10 \mathrm{~m} . \mathrm{y}$. would represent an average rate of $10 \mathrm{~cm} / 10^{3} \mathrm{yr}$, a relatively high rate for 


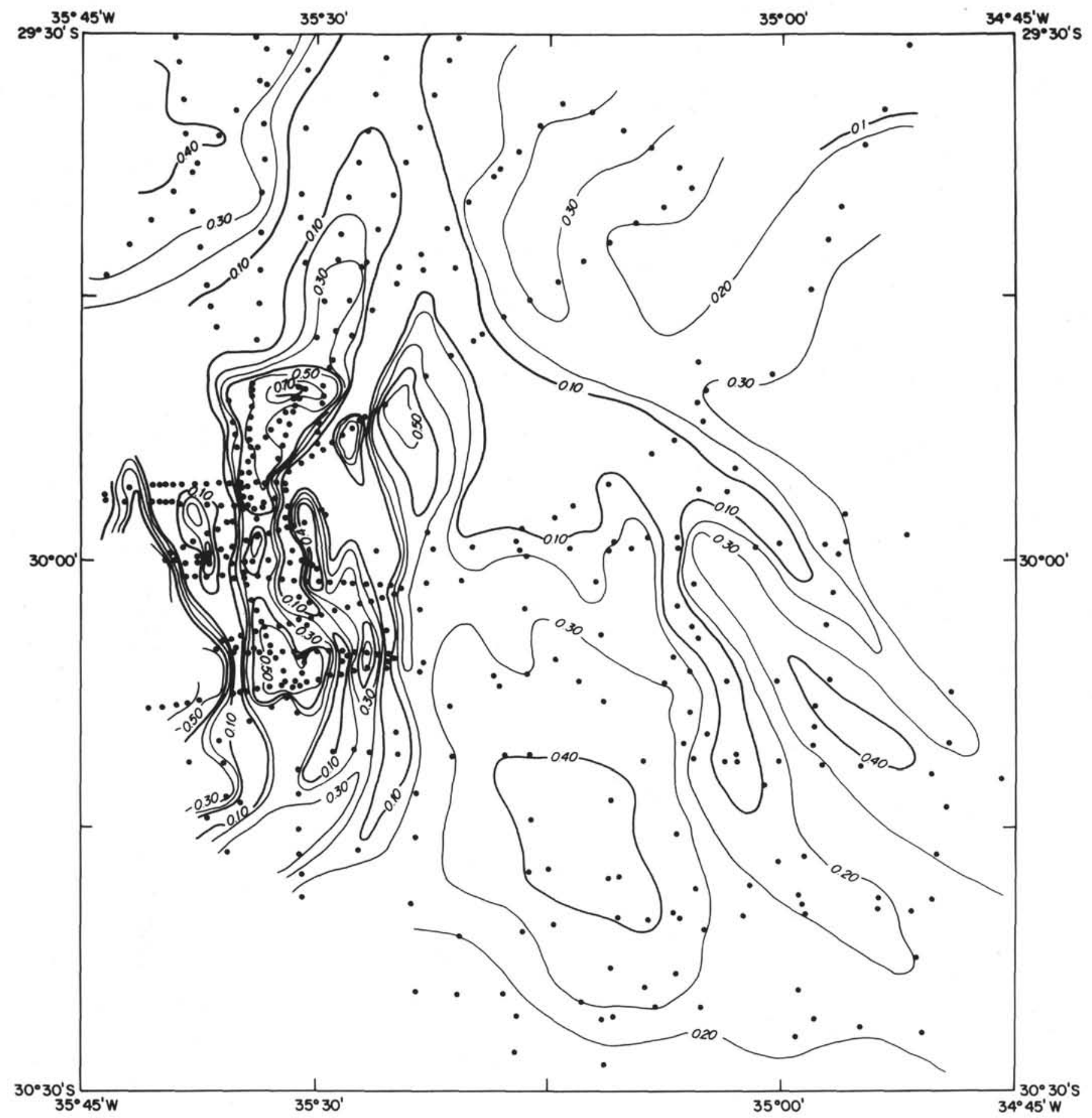

Figure 10. Sediment thickness above the shallowest reflector (Reflector 1, see chapter on Site 357, this volume) in the survey area. Contour interval is $0.10 \mathrm{sec}$ two-way travel time. Reflector 1 can be seen in profiles $C C^{\prime}, D D^{\prime}, E E^{\prime}, F F^{\prime}$ (Figures 6 and 7) marking the base of an upper acoustically "transparent" layer.

calcareous pelagic sediments. Perhaps the layer represents a volcanic capping which forms part of the rise. Such layers with velocities approximately 3.5 $\mathrm{km} / \mathrm{sec}$ have been noticed beneath aseismic rises throughout the world, e.g., Ceará Rise (Houtz et al, 1977), and Kerguelen Plateau, Emperor Seamount Chain, Cocos Ridge, etc. (Houtz, personal communication, 1975). Under Ceará Rise, the 3.5 $\mathrm{km} / \mathrm{sec}$ layer forms smooth acoustic basement (see chapter on Site 354, this volume and also Kumar and Embley, 1977). Because the measured sonic velocity in the drilled limestone at Site 357 is only 2.5 $\mathrm{km} / \mathrm{sec}$, we suggest that it represents the top of a thin sedimentary sequence overlying a 1-km-thick layer of volcanic material. Assuming an average sedimentation rate of $2 \mathrm{~cm} / 10^{3} \mathrm{yr}$, approximately 200 meters of limestone could have been deposited if the extrapolated age for the basement at Site 357 is correct. 
On profile $\mathrm{MM}^{\prime}$ (Figures 1 and 7) a reflector, which may be the basaltic basement, lies approximately 0.25 sec below the limestone reflector. Assuming a velocity of $2.5 \mathrm{~km} / \mathrm{sec}$ measured for the limestone at Site 357 , this difference in time represents 300 meters. At least two other points where the acoustic basement beneath the limestone reflector is visible can be seen (marked on Figure 1 as "2" on the Challenger track and " 3 " on profile $\mathrm{II}^{\prime}$, note the basement peak and the limestone reflector toward the right end of profile II' in Figure 7). Because these areas (1,2, and 3 on Figure 1) are near the western edge of the rise where the crust is presumably older than the crust at Site 357 , the limestone sequence is probably thicker there than at Site 357 . With the limestone reflector at $80 \mathrm{~m} . \mathrm{y}$. and the crust near the western end of the rise at $95 \mathrm{~m} . \mathrm{y}$. old, the gap of $15 \mathrm{~m} . \mathrm{y}$. would be represented by an accumulation of 300 meters of sediment deposits at an average rate of $2 \mathrm{~cm} / 10^{3} \mathrm{yr}$.

The depth to the limestone reflector hence may be used as an approximate indicator of depth to the 3.6 $\mathrm{km} / \mathrm{sec}$ layer for most of the rise (the acoustic basement). True oceanic basement probably lies $1 \mathrm{~km}$ deeper.

\section{SEDIMENTS}

Twenty-two piston cores were obtained within $6 \mathrm{~km}$ of Site 357 during Cruise 115 of R/V Chain (Johnson, 1974; Johnson et al., 1975). The sediment recovered in each of the cores consists of late Pleistocene foram ooze which unconformably overlies Tertiary foram-nanno ooze. Although some cores consist entirely of Pleistocene sediment, the thickness of Pleistocene material is generally on the order of 1 meter. The Tertiary sediments in the Chain cores range in age from middle Pliocene (approximately 3 m.y.) to late Eocene (approximately $40 \mathrm{~m} . \mathrm{y}$.). The age of the Tertiary sediment in each core varies according to the depth of the core site within the study area (Johnson, 1974). Cores from depths approaching those in the axes of the canyons generally contain older Tertiary material; cores from shallower depths contain younger material.

The isopach map of Figure 10 closely resembles the bottom morphology shown in Figure 3. Unless we assume nonuniform sedimentation over Reflector 1, extensive erosion of these canyons is indicated following the formation of this reflector (Reflector 1 is basal Miocene: see chapter on Site 357, this volume). Furthermore, paleomagnetic stratigraphy of two of the sediment cores reveals that the Pleistocene sediment above the unconformity is normally magnetized. Supported by the faunal assemblage this indicates a Brunhes age $(<700,000 \mathrm{yr})$, and thus the major erosional episode responsible for the formation of the extensive channels on the north flank of the rise is most likely a relatively recent event (Johnson et al., 1975).

Present near-bottom flow conditions on the Rio Grande Rise are essentially unknown. Bottom photographs obtained during May 1974 (Figure 11; Stations 132 and 136, R/V Chain, Cruise 115; locations on Figure 3) suggest modest currents in the vicinity of Site 357. Figure 11 (A and B) (Station 132 on Figure 3) are photographs taken on the slope of a channel located a few kilometers to the northeast of Site 357. From the orientation of the ripple marks in these photographs, one may infer near-bottom flow to the northwest, or roughly parallel to the local bottom contours. Figure 11 (C and D) (Station 136 on Figure 3) are bottom photographs taken within the axis of a broad channel approximately $30 \mathrm{~km}$ to the north of Site 357 . Depressions and mounds in the unconsolidated sediments were probably caused by burrowing organisms. In contrast to the suggested current activity at Station 132 (Figure 11A and B), Station 136 (Figure $11 \mathrm{C}$ and D) appears to be in a region of little or no bottom current activity at the present time.

The presence of late Pleistocene sediment above the erosional unconformity suggests that the canyons are perhaps not being actively eroded under present-day conditions. The precise timing of the erosional events, and the mechanisms responsible, remain uncertain. A subsidence of more than $2 \mathrm{~km}$ of the main platform of the Rio Grande Rise since the Santonian has been documented by the drilling data at Site 357 (see chapter on Site 357, this volume). The possibility thus exists that the canyon system was initiated during the late Mesozoic or early Cenozoic and has been maintained ever since. Good core penetration was obtained in calcareous oozes of Pliocene through middle Miocene age but the outcropping chalks of lower Miocene to Eocene age display a higher degree of lithification. This suggests that the outcropping Tertiary strata may have been under a substantial overburden until recently, and that the erosional event took place relatively recently (Johnson, 1974, Johnson et al., 1975). More extensive analysis of the sediments overlying the unconformity may be required to precisely date the main erosional event.

\section{SUMMARY}

1. The east-west segment of the Rio Grande Rise probably originated approximately $100 \mathrm{~m} . \mathrm{y}$. ago as a group of volcanic islands composed of alkalic basalt. A layer, perhaps composed of "volcanic rubble," with a seismic velocity of $3.6 \mathrm{~km} / \mathrm{sec}$ and a thickness of $1 \mathrm{~km}$, mantles the oceanic basement in the region. Based on extrapolation from sea-floor spreading anomalies, the age of the crust underlying Site 357 appears to be approximately $10 \mathrm{~m} . \mathrm{y}$. older than the age of the oldest sediments drilled at the site. The deepest seismic reflector at the drill site, the limestone reflector, represents the top of a calcareous sequence which covers the inferred "volcanic rubble" layer. Westward of Site 357, the crust gets older and the limestone layer covering the volcanic rubble has a thickness greater than at Site 357 . The sedimentary sequence overlying the limestone sequence is 300 to 1100 meters thick in the survey area.

2. Deep erosional canyons dissect much of the north flank of the Rio Grande Rise. The canyons have eroded several hundred meters into the calcareous oozes, chalks, and limestones of Cenozoic, and perhaps even into the sediments of Late Cretaceous age. 

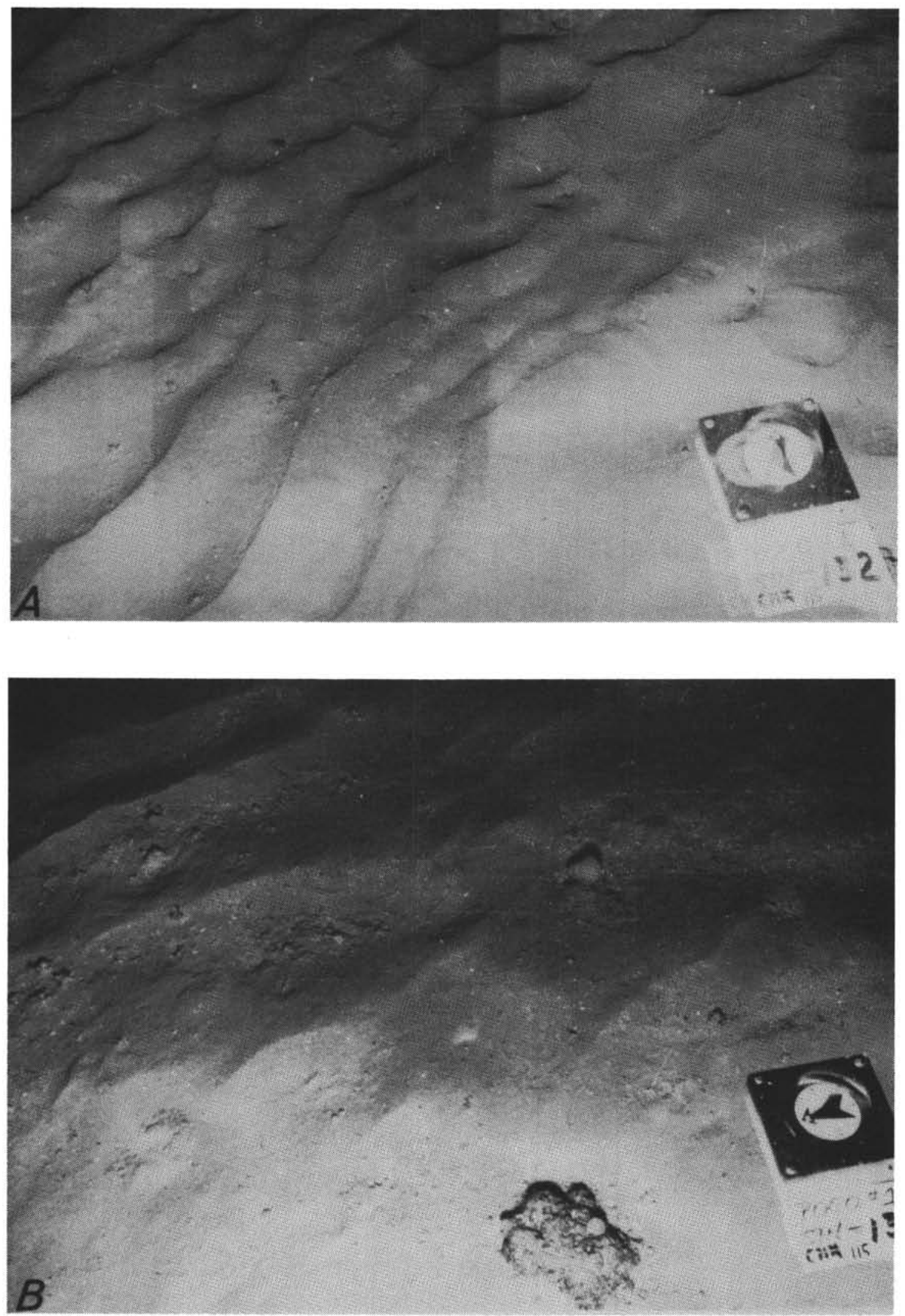

Figure 11 (A and B). Bottom photographs from Station 132 (located on Figure 3). Well developed oscillatory current ripples are seen in the foraminiferal sand of Quaternary age. 

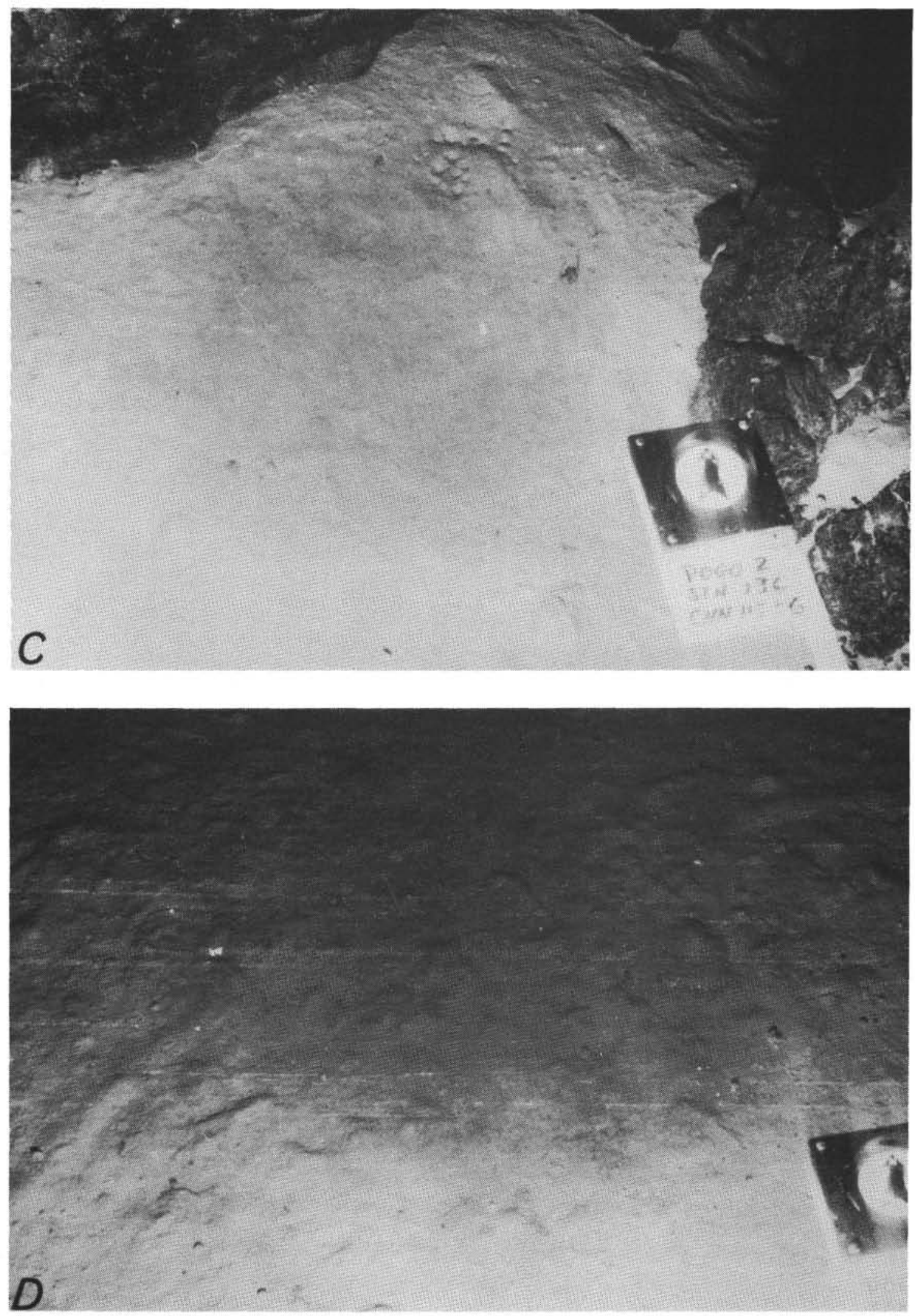

Figure 11 (C and D). Bottom photographs from Station 136 (located on Figure 3). The station is located in the axis of a canyon. Note the abrupt contact between the canyon walls and floor. Small pockets of ponded sediment remain on the canyon walls. Sediment on the canyon floor contains abundant well-preserved mounds and tracks indicative of extensive bioturbation by benthonic macrofauna. Photographs suggest that relatively little current activity is occurring within the canyons at the present time. 
3. An irregular layer of late Pleistocene sediment, ranging in thickness from less than 1 meter to greater than 10 meters, unconformably overlies the erosion surface related to the development of the canyon system. The presence of this late Pleistocene layer, together with the evidence from bottom photographs, indicate that the canyons are not actively being eroded at present. The age of the sediment beneath the late Pleistocene layer ranges from middle Pliocene (approximately $3 \mathrm{m.y}$.) to late Eocene (approximately 40 m.y.) on the upper flanks of the canyons; Cretaceous sediments may outcrop or subcrop in the canyon axes. Caution must be exercised in proposing regional inferences based on the extent of an unconformity at any single location.

4. The time of origin of the canyon system, and the mechanisms responsible, are uncertain. Subsidence of the rise during the Cenozoic has been documented by drilling data and initiation of the canyons in a shallower, more turbulent environment is a possibility. Nevertheless, the evidence from piston cores suggests that much of the erosion on the north flank of the rise took place in late Pleistocene.

\section{ACKNOWLEDGMENTS}

Financial support for this work was provided by the National Science Foundation through the Office for the International Decade of Ocean Exploration under Grant NSF-IDO-72-06426, through the Division of Environmental Sciences under Grants GA 27281 and DES 71-00214, through the Oceanography section under Grant OCE76-09006, and by the Office of Naval Research by Contract N00014-75-C-0210 to the Lamont-Doherty Geological Observatory. Underway data during Cruise Chain 115 were supported under ONR Contract N00014-74-00262 to the Woods Hole Oceanographic Institution. Geological investigations in the Vema Channel, Rio Grande Rise area during Chain 115 were supported under NSF Grant DES 74-01744.

We thank the Department of Submarine Topography of LDGO for allowing us to use part of an unpublished map and are grateful to R.W. Embley and Floyd McCoy of L-DGO and to David Ross and Bilal Haq of WHOI for their constructive criticism of the manuscript.

\section{REFERENCES}

Burckle, L. and Biscaye, P., 1971. Sediment transport by Antarctic Bottom Water through the eastern Rio Grande Rise: Geol. Soc. Am. Abstracts with Programs, v. 3, p. $518-519$.

Connary, S.D., 1972. Investigations of Walvis Ridge and environs: Ph.D. Dissertation, Columbia University, New York, 228 p.

Embley, R. and Hayes, D.E., 1972. Site survey report for Site 142. In Hayes, D.E., Pimm, A.C., et al., Initial Reports of the Deep Sea Drilling Project, Volume 14: Washington (U.S. Government Printing Office), p. 377-388.

Ewing, J., 1969. Seismic model of the Atlantic Ocean. In Hart, P.J. (Ed.), The earth's crust and upper mantle: Am. Geophys. Union Mono. 13, p. 220-225.

Fodor, R.V., Kumar, N., et al., 1975. Petrology of volcanic tuff and breccia from the Walvis seamount province and Rio Grande Rise, South Atlantic Ocean, DSDP Leg 39B:
Geol. Soc. Am. Abstracts with Programs, v. 7, p. 10761077.

Fodor, R.V., Husler, J.W., and Kumar, N., in press. Petrology of volcanic rocks from an aseismic rise: Implications for the origin of the Rio Grande Rise, South Atlantic Ocean: Earth Planet. Sci. Lett.

Francheteau, J. and Le Pichon, X., 1972. Marginal fracture zones as structural framework of continental margins in South Atlantic Ocean: Am. Assoc. Petrol. Geol. Bull., v. 56, p. 991-1007.

Goslin, J. and Sibuet, J.C., 1975. Geophysical study of the easternmost Walvis Ridge, South Atlantic: Deep Structure. Geol. Soc. Am. Bull., v. 86, p. 1713-1724.

Goslin, J., Mascle, J., Sibuet, J.C., and Hoskins, H., 1974. Geophysical study of the easternmost Walvis Ridge, South Atlantic: Morphology and shallow structure: Geol. Soc. Am. Bull., v. 85, p. 619-632.

Houtz, R., Ludwig, W.J., Milliman, J.D., and Grow, J.A., 1977. Structure of the northern Brazilian continental margin: Geol. Soc. Am. Bull., v. 88, in press.

Johnson, D.A., 1974. Initial cruise report, Chain 115, Leg 6: Woods Hole Oceanogr. Inst., Tech. Rept. No. 74-39.

Johnson, D.A., Kumar, N., and Haq, B.U., 1975. Erosional canyons on the north flank of the Rio Grande Rise: evidence of a major late Pleistocene event: Geol. Soc. Am. Abstracts with Programs, v. 7, p. 1135.

Kumar, N. and Embley, R.W., 1977. Evolution and origin of Ceará Rise: an aseismic rise in the western Equatorial Atlantic: Geol. Soc. Am. Bull., v. 88, in press.

Ladd, J.W., 1974. South Atlantic sea floor spreading and Caribbean tectonics: Ph.D. Dissertation, Columbia University, New York, 200 p.

Larson, R.L. and Ladd, J.W., 1973. Evidence for the opening of the South Atlantic in the Early Cretaceous: Nature, v. 246 , p. $209-212$.

Larson, R.L. and Pitman, W.C., III, 1972. World-wide correlation of Mesozoic magnetic anomalies, and its implications: Geol. Soc. Am. Bull., v. 83, p. 3645-3662.

Le Pichon, X. and Hayes, D.E., 1971. Marginal offsets, fracture zones, and the early opening of the South Atlantic: J. Geophys. Res., v. 76, p. 6283-6293.

Le Pichon, X., Ewing, M., and Truchan, M., 1971. Sediment transport and distribution in the Argentine Basin, 2. Antarctic bottom current passage into the Brazil Basin: Phys. Chem. Earth, v. 8, p. 31-48.

Lonardi, A.G. and Ewing, M., 1971. Sediment transport and distribution in the Argentine Basin, 4. Bathymetry of the continental margin, Argentine Basin and other related provinces. Canyons and sources of sediments: Phys. Chem. Earth, v. 8, p. 73-121.

Maxwell, A.E., von Herzen, R.P., et al., 1970. Initial Reports of the Deep Sea Drilling Project, Volume 3: Washington (U.S. Government Printing Office), 806 p.

Morgan, W.J., 1971. Convection plumes in the lower mantle: Nature, v. 230 , p. $42-43$.

Sclater, J.G. and McKenzie, D.P., 1973. Paleobathymetry of the South Atlantic: Geol. Soc. Am. Bull., v. 84, p. 32033216.

Thiede, J., Perch-Nielsen, K., Supko, P.R., Kumar, N., et al., 1975. Sediments on Rio Grande Rise (SW Atlantic Ocean): Subsidence of an aseismic ridge: IX Internat. Congr. Sedimentol., Nice, France, v. 8, p. 67-70.

Wilson, J.T., 1973. Mantle plumes and plate motions: Tectonophysics, v. 19, p. 149-164. 